\title{
Ovarian steroid hormones: what's hot in the stem cell pool?
}

Diana M Cittelly', Jennifer K Richer ${ }^{1}$ and Carol A Sartorius*

\begin{abstract}
The vital role of ovarian hormones in the development of the normal breast foreshadowed their importance in mammary stem cell regulation. Two recent papers reveal that $17 \beta$-estradiol and progesterone control the size and repopulating ability of the mammary stem cell compartment. This likely occurs via paracrine signaling from steroid receptor-positive luminal cells to steroid receptor-negative stem cells. These findings illuminate roles for the female sex steroids in mobilizing the stem cell pool in the normal breast, and also provide a crucial link between the known hormonal risks of breast cancer and the potential stem cell origin of this disease.
\end{abstract}

\section{Background}

Lifetime exposure to circulating steroid hormones via the number of menstrual cycles, menopausal hormone therapy, and perhaps pregnancy all increase breast cancer risk [1]. The details underlying this increased risk, however, have long remained elusive. The re-emergence of the cancer stem cell (CSC) theory since its original inception over a century ago [2] has popularized mammary stem cells (MaSCs) as putative cells of origin for breast cancers. Since the MaSCs reside within the steroid receptor-negative basal epithelial compartment [3], it was presumed that steroid hormone signaling would have little impact on their regulation. This presumption was despite earlier work demonstrating that estrogen receptor (ER)-positive and progesterone receptor (PR)positive luminal cells in the normal breast use a paracrine mechanism to instruct neighboring ER-negative/PRnegative cells to proliferate [4]. Two seminal papers now uncover a critical role for steroid hormones in controlling both the number and the regenerative function of MaSCs

*Correspondence: Carol.Sartorius@ucdenver.edu

2Department of Medicine, Division of Endocrinology, University of Colorado

Anschutz Medical Campus, Aurora, CO 80045, USA

Full list of author information is available at the end of the article in the normal murine mammary gland. These exciting findings promise to revolutionize our perception of how the female sex steroid hormones regulate the differentiation state of the breast and influence the risk of breast disease $[5,6]$.

\section{The articles}

Asselin-Labat and colleagues establish that steroid hormone deprivation via ovariectomized or aromatasedeficient mice significantly reduces the ability of MaSCs $\left(\mathrm{CD} 29^{\text {hi }} \mathrm{CD} 24^{+}\right)$to repopulate a mammary gland in the cleared fat pad of syngeneic recipient mice [5]. A combination of $17 \beta$-estradiol plus progesterone, but not $17 \beta$-estradiol or progesterone alone, in ovariectomized mice restores the repopulating frequency of MaSCs. Blockade of either $17 \beta$-estradiol (letrozole) or progesterone (RU486) did not affect MaSC numbers, but did reduce their repopulating ability and ductal outgrowth formation, respectively - indicating that MaSCs rely on the luminal compartment for functional signals. Interestingly, the hormonal state of the donor imprints its mark on the repopulating ability of MaSCs.

In a parallel article, Joshi and colleagues demonstrate that the MaSC population $\left(\mathrm{CD} 29^{\mathrm{hi}} \mathrm{CD} 49 \mathrm{f}^{\mathrm{hi}} \mathrm{CD} 24^{+}\right)$fluctuates with the mouse estrous cycle [6]. Specifically, high serum progesterone levels at diestrous, or when given exogenously to ovariectomized mice, are responsible for the increase in MaSCs. The authors propose that the major role of $17 \beta$-estradiol is to induce expression of PR, which mediates the progesterone-driven MaSC expansion. MaSC proliferation is accompanied by increased apoptosis, which assists in returning MaSC numbers to baseline levels after each cycle. Aged, noncycling mice have a static MaSC population, further underscoring hormonal involvement.

Both of these articles implicate paracrine signaling from the ER-positive/PR-positive luminal epithelial compartment in control of MaSC expansion [5,6]. RANK ligand, which is progesterone regulated [7], was identified as a key paracrine factor involved in mediating MaSC division. Abolishing RANK signaling disrupted the ability of luminal cells to stimulate MaSC division [5], indicating that RANK ligand is at least one factor that transmits the 
hormonal signal. The crux of these data is that the MaSC population is dynamic, not static, and is notably cued by the hormone state.

\section{The viewpoint}

These studies in the murine mammary gland will probably drive further research into the influence of hormones on stem cells in humans, not only in the breast but in other tissues as well. Indeed, in the normal human breast, progesterone was recently found to increase the number of progenitor cells [8]. The hormone-driven risk of breast cancer in women may be tied to the extent of expansion/retraction of the transformation-sensitive MaSC population.

The discussed studies lead to the question of whether hormones regulate a CSC component in human breast cancers. Breast CSCs appear to be steroid receptornegative [9], and in luminal tumors, at least, could be regulated by surrounding ER-positive/PR-positive cancer cells. Indeed, xenograft tumors grown from breast cancer cell lines have an increased number of cells with an ERnegative/PR-negative CSC phenotype when grown with both $17 \beta$-estradiol and progesterone, compared with $17 \beta$-estradiol alone [10]. This suggests that progesterone can expand stem cells in malignant tissue as well as in normal tissue [8]. It is possible that the quiescent stem cell population in postmenopausal women could be mobilized during progestin-containing hormone therapies, accounting for the higher incidence of breast cancer in such cases. The fact that PR is critical for murine mammary tumorigenesis [11] further emphasizes a role for progesterone signaling in human breast tumor formation.

The fluctuation in MaSC numbers in the normal gland suggests a potential plasticity in breast CSC numbers. The observed stasis returned after cycles, pregnancy, and aging in the models may not be complete in some women, leading to higher risk of mutation and disease. Individual variability in the number of MaSCs combined with genetic influences probably affects susceptibility to breast cancer. An expanded CSC population could also adversely affect treatment response or risk of recurrence.

It is of note that MaSCs are dependent on a healthy, functioning luminal cell compartment. In breast cancer, antiestrogen therapies that attack the luminal population could indirectly ablate CSCs. In endocrine-resistant tumors, CSCs could have lost their dependence on the luminal ER-positive/PR-positive cells. Lim and colleagues suggest that the potential cell of origin of basal steroid receptor-negative cancers is a luminal progenitor [12], normally reliant on steroid hormone signaling [5]. These progenitors may lose their hormone dependence early in transformation. Deciphering a potential luminal cell/ stem cell interaction in breast cancer may divulge new targets for treatment of this disease.
In summary, the two profiled articles unearth a new paramount role for a steroid-sensitive luminal cell niche in regulating MaSCs. If the latter are indeed the cells of origin for breast cancers, then ovarian hormones do control the degree of risk for this disease. Progesterone has a historical reputation as a differentiating hormone, and it may well be, at least in luminal cells, destined towards terminal differentiation. However, progesterone is evidently even more important than $17 \beta$-estradiol in regulating stem cell populations, thereby altering our perception of its role in both the normal breast and breast cancer.

\section{Abbreviations}

CSC, cancer stem cell; ER, estrogen receptor; MaSC, mammary stem cell; PR, progesterone receptor; RANK, receptor activator for nuclear factor $\mathrm{KB}$.

\section{Competing interests}

The authors declare that they have no competing interests.

\section{Author details}

'Department of Pathology, University of Colorado Anschutz Medical Campus, Aurora, CO 80045, USA. ²Department of Medicine, Division of Endocrinology, University of Colorado Anschutz Medical Campus, Aurora, CO 80045, USA.

\section{Published: 31 August 2010}

\section{References}

1. Bernstein L: Epidemiology of endocrine-related risk factors for breast cancer. J Mammary Gland Bio/ Neoplasia 2002, 7:3-15.

2. Sell S: Stem cell origin of cancer and differentiation therapy. Crit Rev Oncol Hematol 2004, 51:1-28.

3. Asselin-Labat ML, Shackleton M, Stingl J, Vaillant F, Forrest NC, Eaves CJ, Visvader JE, Lindeman GJ: Steroid hormone receptor status of mouse mammary stem cells. J Natl Cancer Inst 2006, 98:1011-1014.

4. Clarke RB, Howell A, Potten CS, Anderson E: Dissociation between steroid receptor expression and cell proliferation in the human breast. Cancer Res 1997, 57:4987-4991.

5. Asselin-Labat ML, Vaillant F, Sheridan JM, Pal B, Wu D, Simpson ER, Yasuda H, Smyth GK, Martin TJ, Lindeman GJ, Visvader JE: Control of mammary stem cell function by steroid hormone signalling. Nature 2010, 465:798-802.

6. Joshi PA, Jackson HW, Beristain AG, Di Grappa MA, Mote PA, Clarke CL, Stingl J, Waterhouse PD, Khokha R: Progesterone induces adult mammary stem cell expansion. Nature 2010, 465:803-807.

7. Mulac-Jericevic B, Lydon JP, DeMayo FJ, Conneely OM: Defective mammary gland morphogenesis in mice lacking the progesterone receptor $B$ isoform. Proc Natl Acad Sci U S A 2003, 100:9744-9749.

8. Graham JD, Mote PA, Salagame U, van Dijk JH, Balleine RL, Huschtscha LI, Reddel RR, Clarke CL: DNA replication licensing and progenitor numbers are increased by progesterone in normal human breast. Endocrinology 2009, 150:3318-3326.

9. Shipitsin M, Campbell LL, Argani P, Weremowicz S, Bloushtain-Qimron N, Yao J, Nikolskaya T, Serebryiskaya T, Beroukhim R, Hu M, Halushka MK, Sukumar S, Parker LM, Anderson KS, Harris LN, Garber JE, Richardson AL, Schnitt SJ, Nikolsky Y, Gelman RS, Polyak K: Molecular definition of breast tumor heterogeneity. Cancer Cell 2007, 11:259-273.

10. Horwitz KB, Dye WW, Harrell JC, Kabos P, Sartorius CA: Rare steroid receptornegative basal-like tumorigenic cells in luminal subtype human breast cancer xenografts. Proc Natl Acad Sci U S A 2008, 105:5774-5779.

11. Lydon JP, Ge G, Kittrell FS, Medina D, O'Malley BW: Murine mammary gland carcinogenesis is critically dependent on progesterone receptor function. Cancer Res 1999, 59:4276-4284.

12. Lim E, Vaillant F, Wu D, Forrest NC, Pal B, Hart AH, Asselin-Labat ML, Gyorki DE, Ward T, Partanen A, Feleppa F, Huschtscha LI, Thorne HJ; kConFab, Fox SB, Yan M, French JD, Brown MA, Smyth GK, Visvader JE, Lindeman GJ: Aberrant luminal progenitors as the candidate target population for basal tumor development in BRCA1 mutation carriers. Nat Med 2009, 15:907-913.

doi: $10.1186 /$ bcr2627

Cite this article as: Cittelly DM, et al:: Ovarian steroid hormones: what's hot in the stem cell pool? Breast Cancer Research 2010, 12:309. 